\title{
Examination of the Quality Indicators of Haraz River Water, Inflow and Outflow of Water of Fish Farm
}

\author{
Azam Ali Khademi ${ }^{1}$, Mahsa Najafi ${ }^{1}$, Shahrzad Khoram Nejadian ${ }^{1} \&$ Babak Moghadas ${ }^{2}$ \\ ${ }^{1}$ Department of Environmental and Natural Source, Damavand Azad University, Iran \\ ${ }^{2}$ Department of Agriculture and Natural Source, Savad Kooh Azad University, Iran \\ Correspondence: Azam Ali Khademi, Department of Environmental and Natural Source, Damavand Azad \\ University, Iran.
}

Received: October 24, 2020

Accepted: May 24, 2021

Online Published: May 24, 2021

doi:10.5539/mas.v15n3p31

URL: https://doi.org/10.5539/mas.v15n3p31

\begin{abstract}
This study was an attempt to examine the quality indicators of Haraz River water inflow and outflow of water of fish farms. This study aimed to prove and assess the water pollution status of Haraz River and investigate the impact of fish farms on river water quality. Sampling was performed in two seasons of summer and autumn of 2015 in seven stations of river water and inflow and outflow of farms water. Quality pollution index includes (temperature, phosphate, nitrate, nitrite, ammonia, electrical conductivity, BOD, COD, PH Were measured. Comparison of the results with the allowable values of Iran code and waste water standards showed that the factors in all samples and both seasons were in the allowable range and the rate of these indicators in autumn is higher than the summer. The amount of ammonia, carbon and total phosphate in summer is higher than the autumn. The findings of the results reveal that the proper quality and cleanliness of Haraz River water in the study area show that the activity of farms doesn't have a significant effect on the quality index of Haraz River water.
\end{abstract}

Keywords: Haraz river, quality river indicators, fish farming, salmon

\section{Introduction}

Haraz River is one of the most important water resources in Mazandaran province. The development of aquaculture activities on the banks of the Haraz River can play a major and influential role in the economic, social and cultural development of the province especially with Larijan region (Sepahdari, Saeedi, Kakolki, Shapoor, Habibi Kotnaei, Farshideh, \& Babaalian, 2013). Haraz River is one of the most active rivers in the south basin of the Caspian Sea. The river originates from the eastern slope of the Palan Mountain that is located in the eighty kilometers south west of Amol and seventy kilometers south west of Noor (Bergheim, A., \& Selmer-Olsen, A. R. 1978).

The annual water meters, which is more watery in spring ( 464 million cubic meters) and less watery in winter (132 million cubic meters)? (General Department of Fisheries of Mazandaran Province, 2005) Water quality is a demining factor for human well-being. The spread of disease is inevitable in communities with contaminated water, bacteria and chemicals and many deaths are caused by water pollution (Ismail Sari, 2004).

Given that in recent years the rate of pollution of rivers and seas has been increasing and Iran is no exception in this rule, it is necessary to improve the conditions of clean (blue) environments and environmental conditions, as well as human societies activities such as conducting this research should be carried out through environmental studies in the region. In the process of reproduction and breeding of fish, three types of waste are produced, including solids, soluble substances, and chemicals and drugs. (Ismail Sari, 2004) Sedimentary solids and suspended solids, including faces, indigested food, soluble waste materials, including nitrogen and soluble phosphorus, which are the result of fish metabolism and waste decomposition. Chemicals and medicines from residual drug treatments such as copper and formalin sulfates, fungicides such as malachite green, and various types of antibiotics such as sulfonamides, even in relatively small amounts, can exacerbate chemical disorders. (Zamanpour. 2008) In the similar study, the results reveal that Khazemzadeh Khajoui and colleagues examined the contamination of fish farms in the Haraz River. The results showed that there was a significant correlation between aquaculture density and ammonium density. (Khajoui et al., 2002) 
According to Nader Jelodar and colleagues, the values of the parameters in different stations have fluctuations and some of them and include (Oo, TSS, NH4) turbidity in different stations that show a significant difference which is the result of the effect of fish farms and river self-purification. (Jelodar et al., 2011)

The studies of Ardakani et al revealed that the effect of effluent on fish breeding and breeding work place on the physical and chemical quality of the Kabkian River in Kohgiluyeh and Boyer Ahmad provinces showed that the Kabkian River is currently self-purifying, but with increasing number of breeding work place fish farming as well as the lack of monitoring. (Ardakani et al., 2011)

\section{Methodology}

In order to examine this study, the researchers examine Haraz river water quality index, inflow and outflow water of fish farms in Ab-e-Ask and Gazanak. Sampling was performed in two season of summer and autumn of 2015 in seven stations of Haraz River (table 1) in this area, three fish farms were surveyed.

The firs area includes a workshop called Ghezel sarab with an annual production of 107 tons of fish and a flow rate of 350 liters per second. The second or downstream area consist of two workshops in series, each with the names of Ghezel and Nel Ghezel, producing water consumption of 980 and 250 liters per second, respectively, 186 and 50 tons of fish per year. (Statistical Yearbook of Iran Fisheries Organization, 2009)

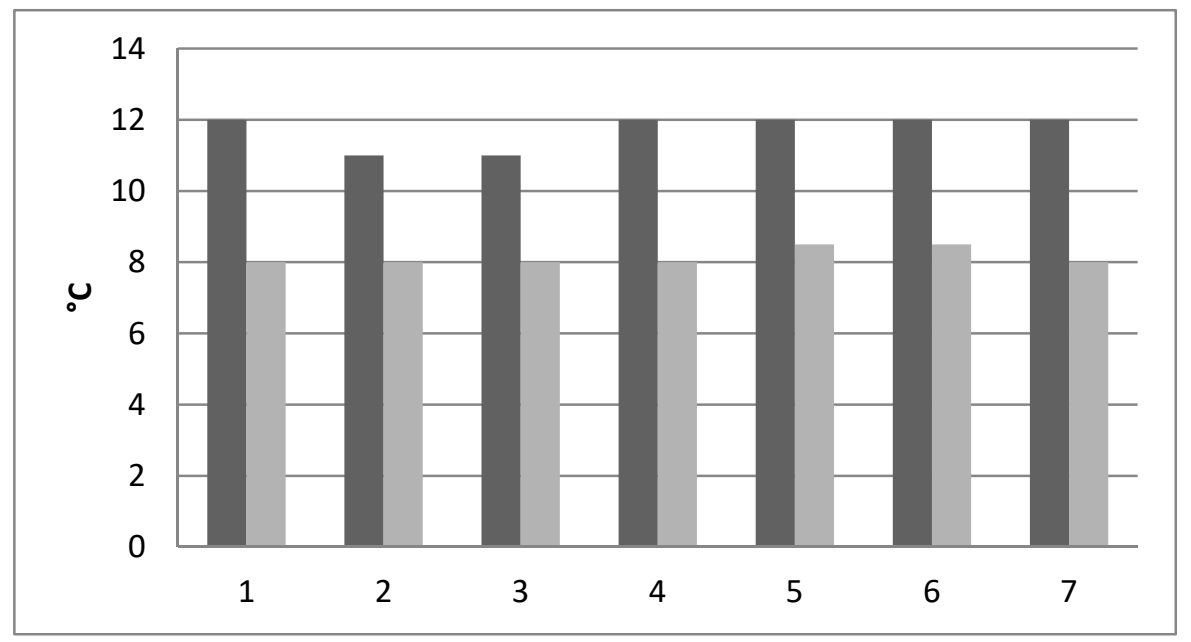

Figure 1. Comparison of water temperature in sampling stations in Haraz River in Autumn \& Summer

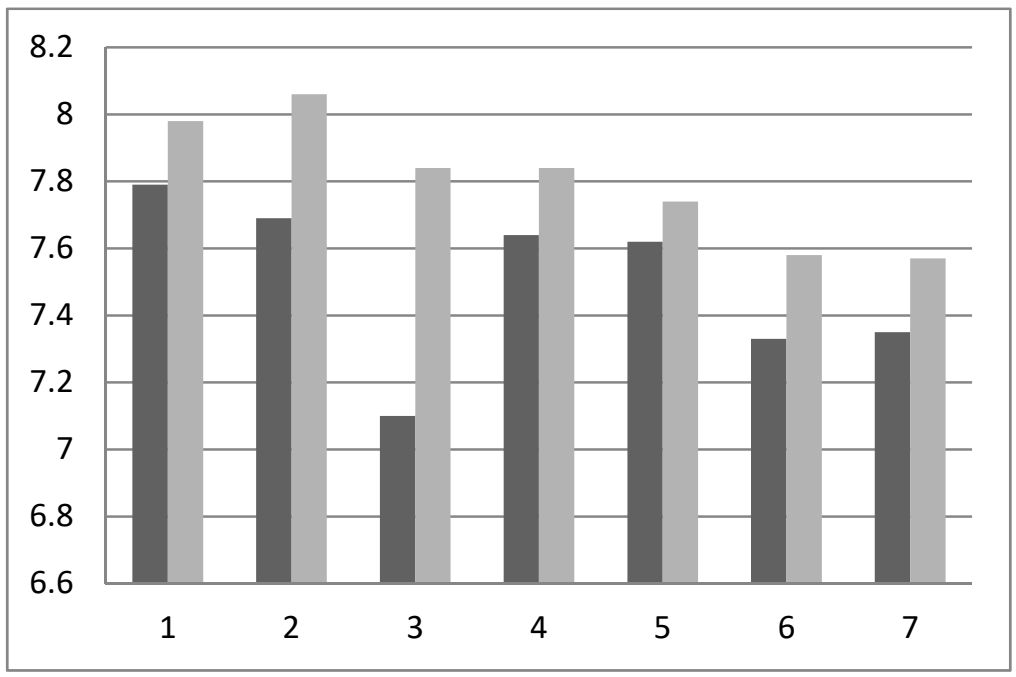

Figur 2. Comparison of water $\mathrm{pH}$ in sampling stations in Haraz River in Autumn \& Summer 


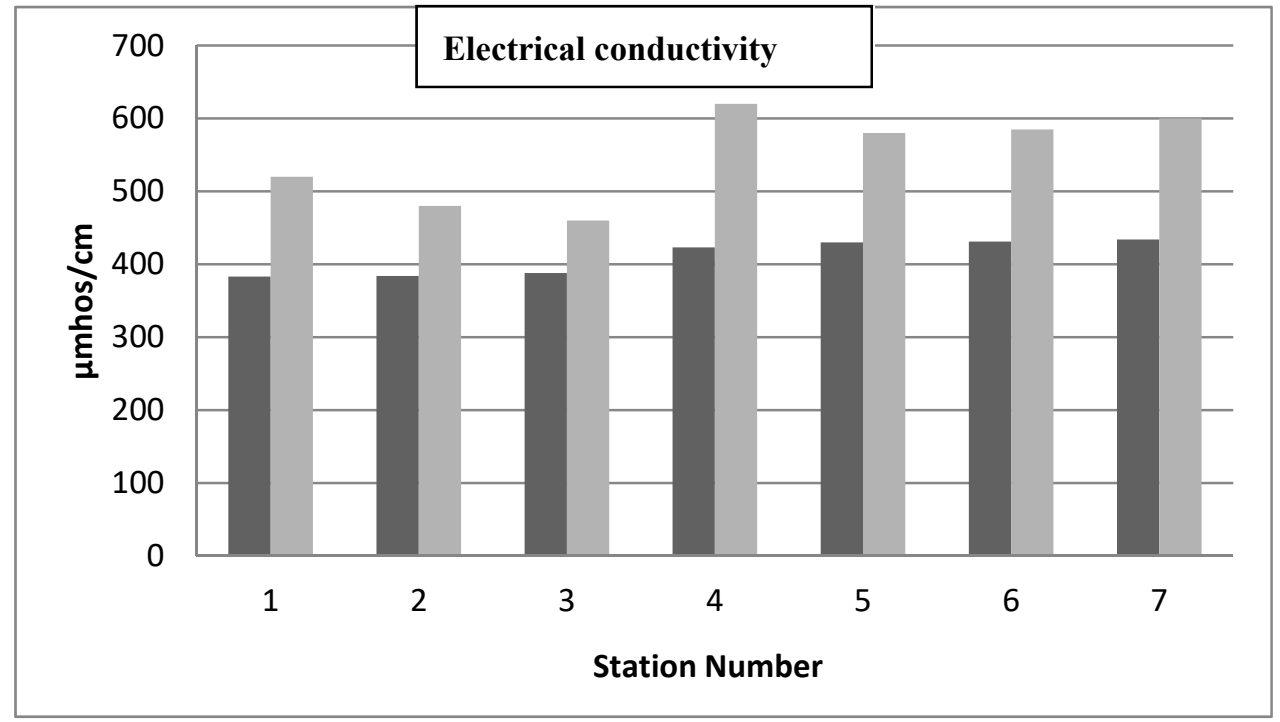

Figure 3. Comparison of EC parameter in sampling stations in Haraz River in Summer \& Autumn

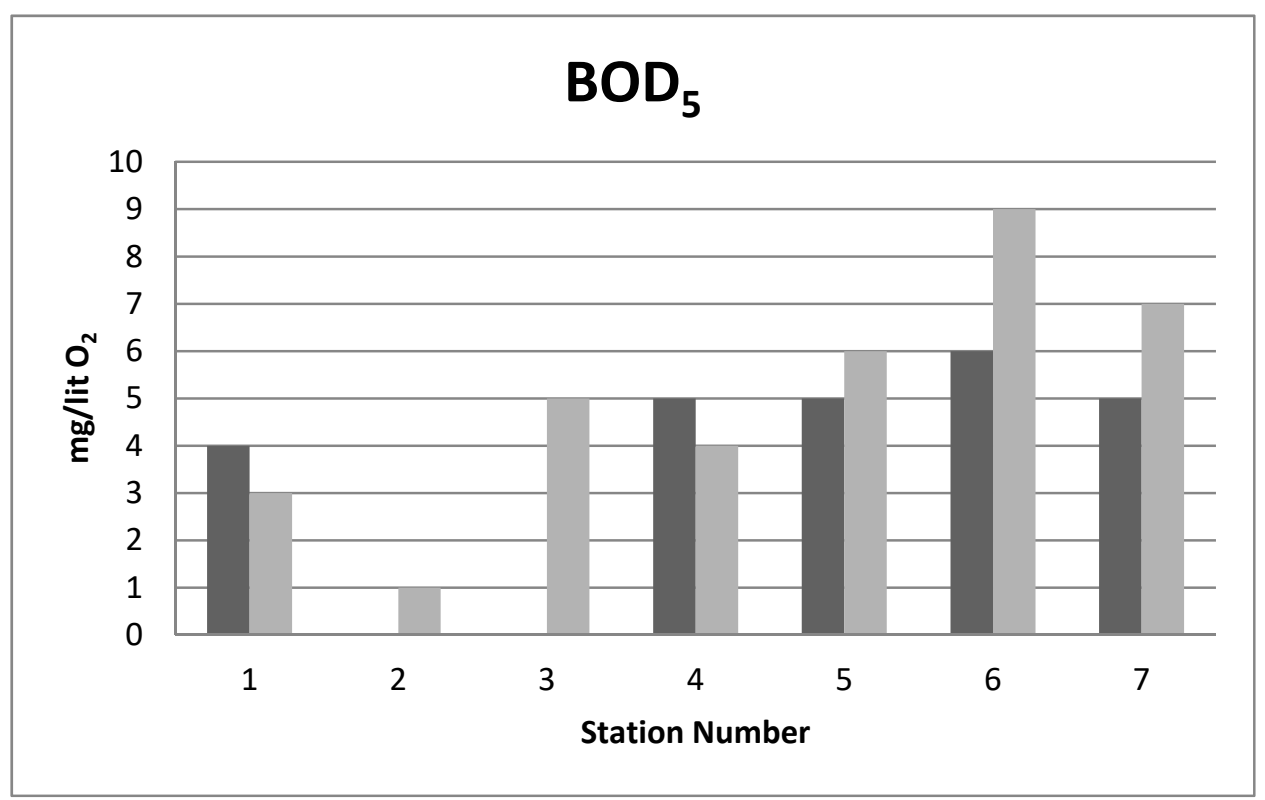

Figure 4. Comparison of BOD parameter in sampling stations in Haraz River 


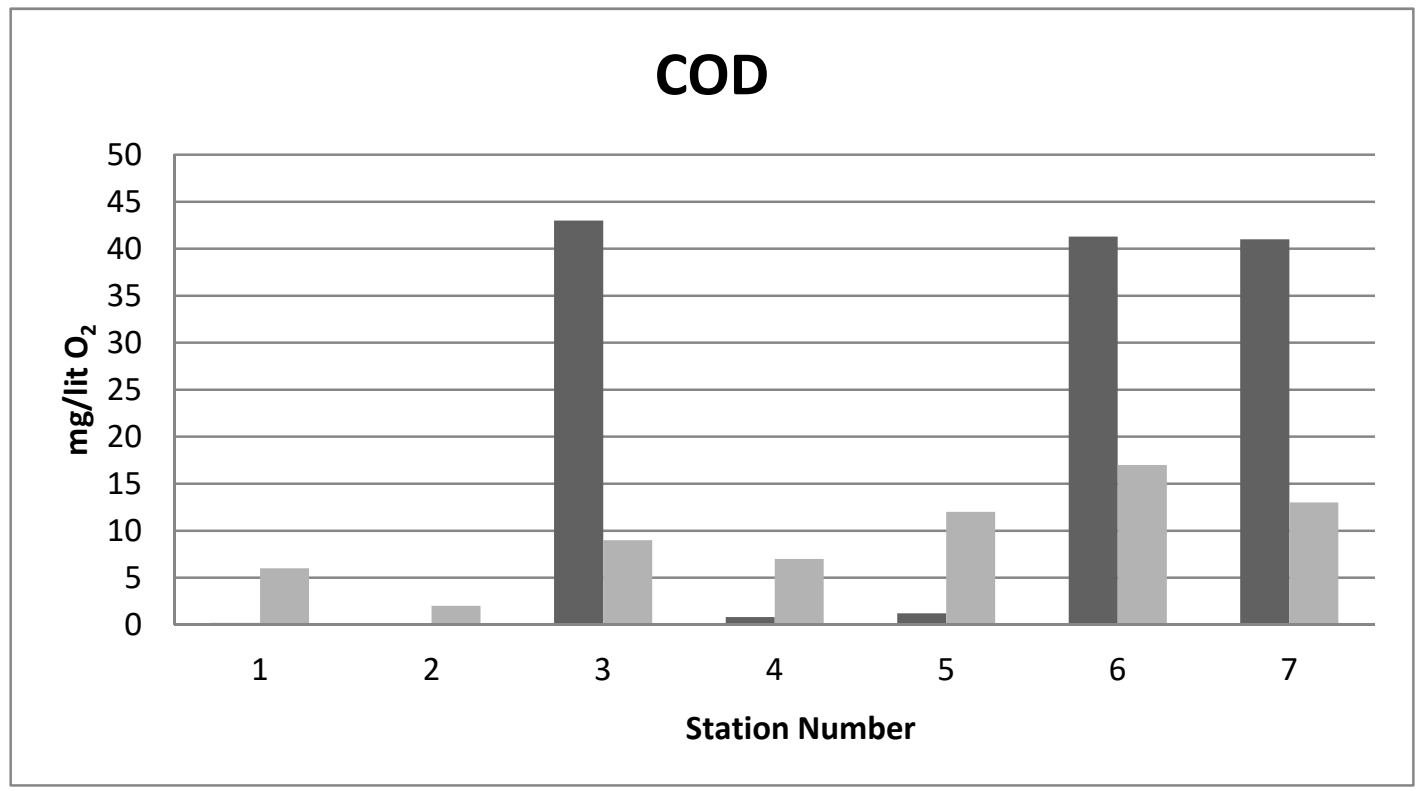

Figure 5. Comparison of COD parameter in sampling stations in Haraz River in autumn \& summer

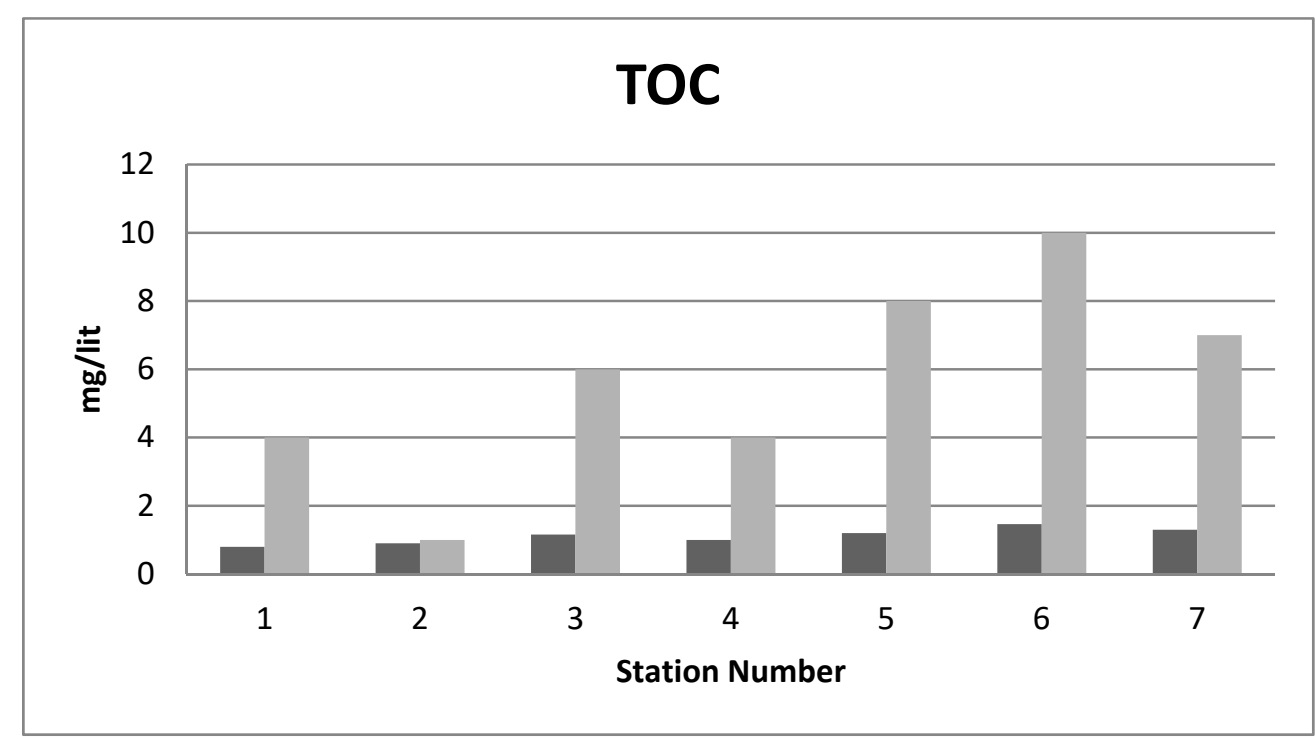

Figure 6. Comparison of TOC parameter in sampling stations in Haraz River in Autumn \& Summer 


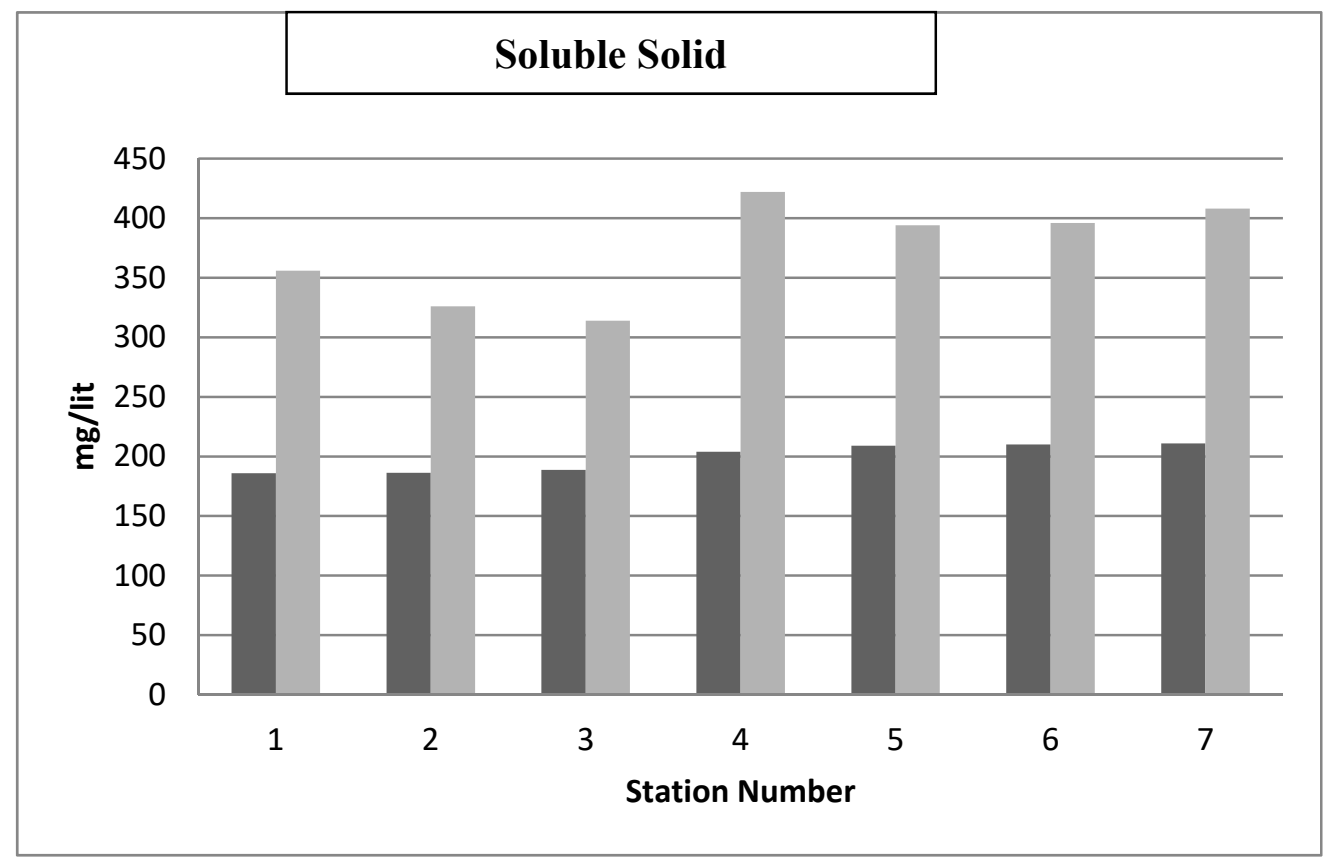

Figure 7. Comparison of TDS parameter in sampling stations in Haraz River

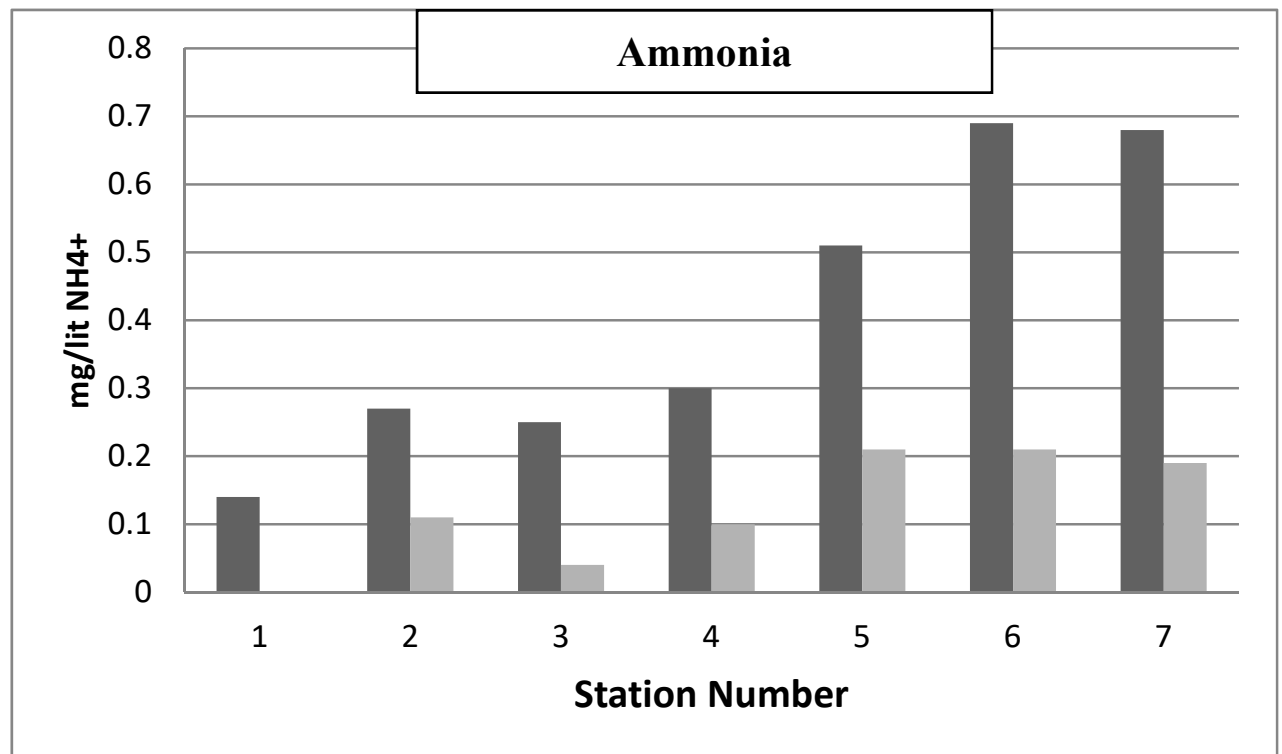

Figure 8. Comparison of NH4 + parameter in sampling stations in Haraz River in Summer \& Autumn 


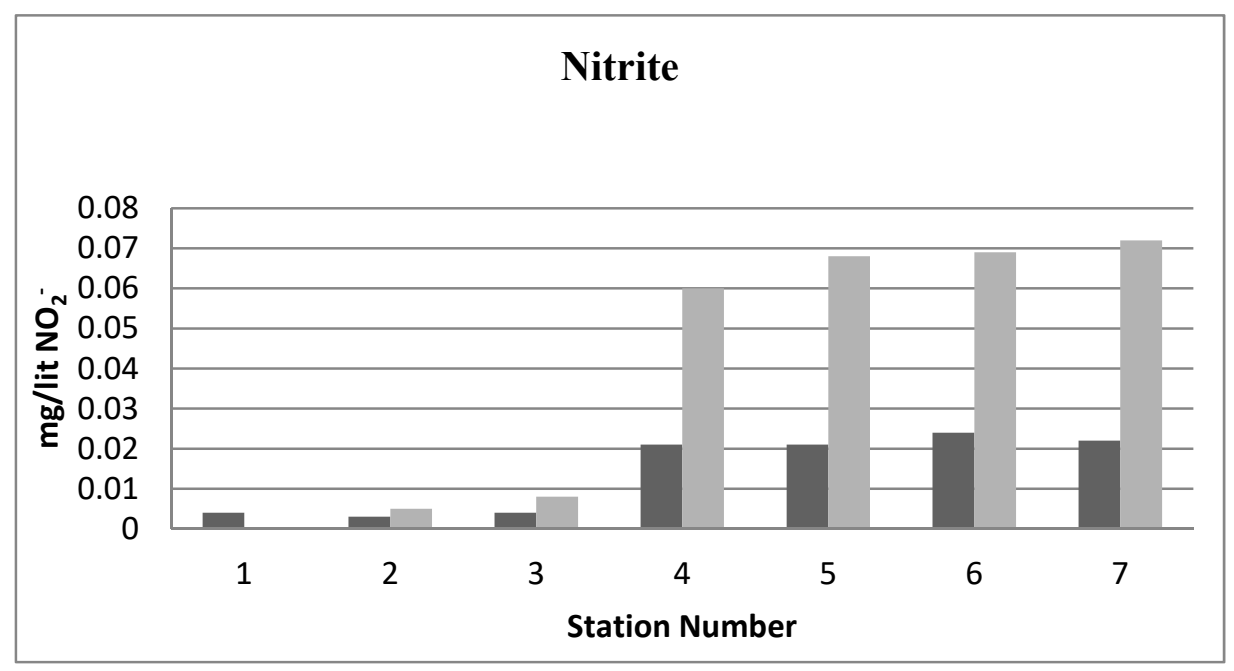

Figure 9. Comparison of NO2- parameter in sampling stations in Haraz River in Autumn \& Summer

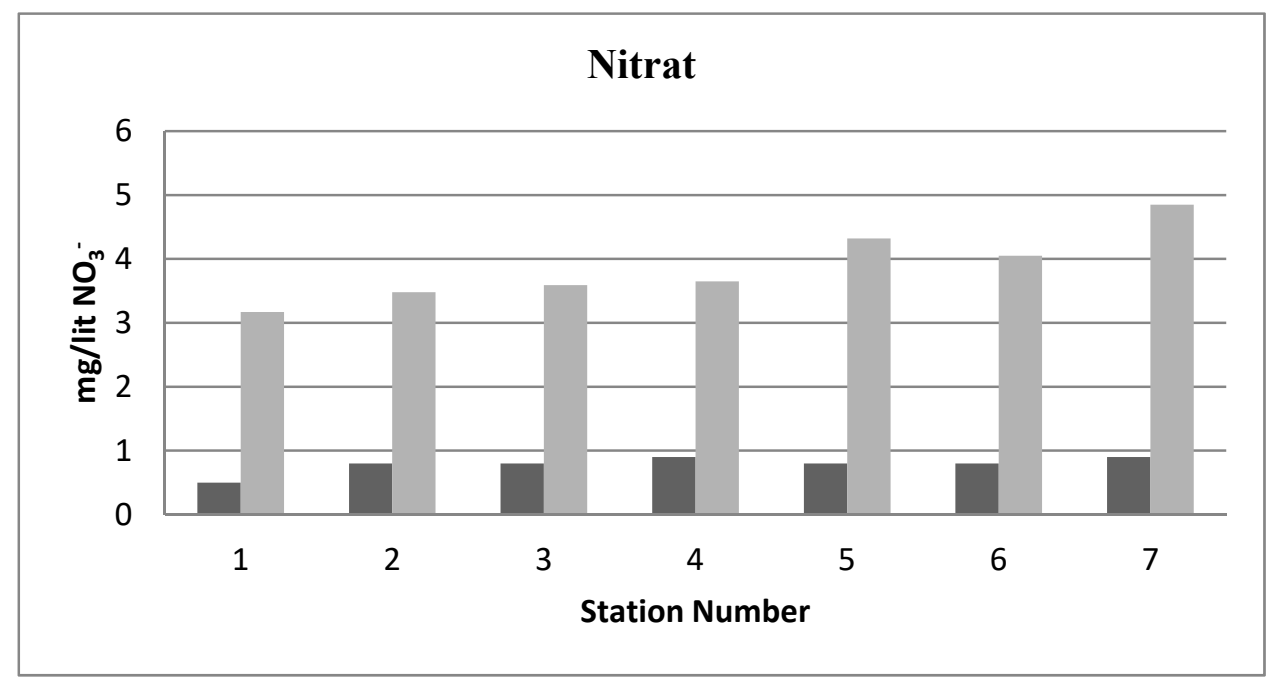

Figure 10. Comparison of NO3- parameter in sampling stations in Haraz River in Autumn \& Summer

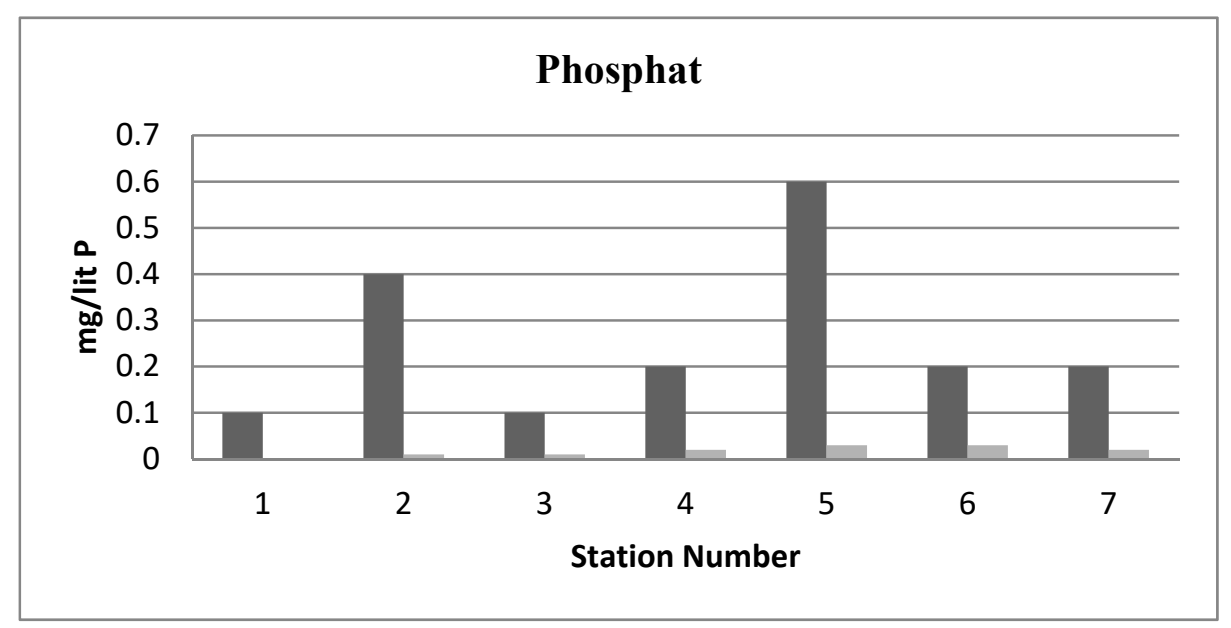

Figure 11. Comparison of PO3 parameter- in sampling stations in Haraz River in Autumn \& Summer 
Table 1. Results of statistical analysis studies

\begin{tabular}{|c|c|c|c|}
\hline Variable & Period & Rate $t$ & sig \\
\hline \multirow{3}{*}{ Temperature } & Autumn & -2.000 & 0.184 \\
\hline & Summer & -2.000 & 0.184 \\
\hline & Average & -2.000 & 0.184 \\
\hline \multirow{3}{*}{ pH } & Autumn & 4.536 & 0.045 \\
\hline & Summer & -0.029 & 0.980 \\
\hline & Average & 2.206 & 0.158 \\
\hline \multirow{3}{*}{ Electrical conductivity } & Autumn & 4.391 & 0.048 \\
\hline & Summer & -24.826 & 0.0012 \\
\hline & Average & 2.639 & 0.119 \\
\hline \multirow{3}{*}{ BOD $_{5}$} & Autumn & -2.447 & 0.109 \\
\hline & Summer & -2.619 & 0.0120 \\
\hline & Average & -2.750 & 0.111 \\
\hline \multirow{3}{*}{ COD } & Autumn & -2.321 & 0.146 \\
\hline & Summer & -0.038 & 0.973 \\
\hline & Average & -2.297 & 0.148 \\
\hline \multirow{3}{*}{ Total organic carbon(TOC) } & Autumn & -1.808 & 0.212 \\
\hline & Summer & -8.000 & 0.015 \\
\hline & Average & -1.911 & 0.196 \\
\hline \multirow{3}{*}{ Ammonia } & Autumn & -5.286 & 0.034 \\
\hline & Summer & -3.363 & 0.078 \\
\hline & Average & -3.809 & 0.063 \\
\hline \multirow{3}{*}{ Nitrite } & Autumn & -69.545 & 0.0001 \\
\hline & Summer & -20.788 & 0.0012 \\
\hline & Average & -47.600 & 0.0001 \\
\hline \multirow{3}{*}{ Nitrate } & Autumn & -4.030 & 0.056 \\
\hline & Summer & -1.000 & 0.42 .3 \\
\hline & Average & -5.430 & 0.032 \\
\hline \multirow{3}{*}{ Phosphate } & Autumn & -4.000 & 0.057 \\
\hline & Summer & -4.600 & 0.044 \\
\hline & Average & -3.793 & 0.063 \\
\hline \multirow{3}{*}{ Soluble solids(TDS) } & Autumn & -1.034 & 0.410 \\
\hline & Summer & -16.379 & 0.004 \\
\hline & Average & -2.000 & 0.18 .4 \\
\hline
\end{tabular}

Water sampling was performed according to the method of the Iranian institute of standards and industrial research (11). The samples were transferred to the laboratory in ionolithic containers and water pollution quality indicators (temperature, phosphate, Nitrate, Nitrite, ammonia, the amount of soluble solids organic carbon, electrical conductivity BOD, $\mathrm{COD}, \mathrm{pH}$ ) were measured. Accurate thermometry was measured at the sampling site. The $\mathrm{Ph}$. factor was measured using the standard method and $\mathrm{Ph}$. device model $\mathrm{ph}$. Lab.

Ec factor was measured using the electrode method (standard Method No 540 c2) multi meter device American Hack company, Senslon 156 model. BOD factor was measured using Rasp metric (standard Method No B5210), thermostatic incubator model TS 606p-1 in German. 
TDS factor was measured using Electrode method (standard method C2540 no), Multi parameter device, American Hack company, Senslon 156 model. Nitrite factor was measured using Cali metric method (standard method No2b4300) spectrophotometer, American Hack Company, DR2800 model.

Ammonia factor was measured using Neslirizition B1426 No (ASTN), spectrophotometer device, American Hack Company, DR2800 model.

Nitrite factor was measured using Brosin Method (EPH, NO35201) spectrophotometer, American Hack Company, DR2800 model.

Phosphate factor was measured using Stenos Chloride (standard method NO Pd4500). Spectrophotometer, American Hack Company, DR2800 model.

COD factor was measured using cloud Zerflux, Timitric (standard method, CS220), Thermodynamic Actor, German WTW Company, CR2200 model.

TOC factor was measured using oxidation of ultra violet persulfate or Heath persulfate (standard method, NO B5310), Analyzer device (TOC), VWP model Shimatzo.

Table 2. Specification of sampling station in Haraz River

\begin{tabular}{lllll}
\hline District & $\begin{array}{l}\text { Station } \\
\text { number }\end{array}$ & Explanation & $\begin{array}{l}\text { longitude } \\
\left({ }^{\circ} \mathrm{E}\right)\end{array}$ & $\begin{array}{l}\text { Latitude } \\
\left({ }^{\circ} \mathrm{N}\right)\end{array}$ \\
\hline \multirow{2}{*}{ Ab-e-Ask } & 1 & Farm entrance & $35^{\circ}: 861^{\prime}$ & $52^{\circ}: 132^{\prime}$ \\
& 2 & Farm exit & $35^{\circ}: 861^{\prime}$ & $52^{\circ}: 129^{\prime}$ \\
& 4 & The outlet of the farm with the river & $35^{\circ}: 860^{\prime}$ & $52^{\circ}: 128^{\prime}$ \\
Ghazanak & 5 & First farm entrance & $35^{\circ}: 859^{\prime}$ & $52^{\circ}: 212^{\prime}$ \\
& 6 & The first farm exit & $35^{\circ}: 898^{\prime}$ & $52^{\circ}: 216^{\prime}$ \\
& 7 & The second farm exit & $35^{\circ}: 902^{\prime}$ & $52^{\circ}: 220^{\prime}$
\end{tabular}

\section{Discussion}

\subsection{Temperature}

Due to the change in sample temperature because of displacement, the water temperature was measured by an accurate thermometer. The thermometer was placed at a depth of $20 \mathrm{~cm}$ from the water and at a distance from the walls.

The results of temperature measurement showed that, on average, in both Goznak and Ab-e-Ask areas, it was $8^{\circ} \mathrm{C}$ in autumn and $12^{\circ} \mathrm{C}$ in summer (Figure 4). Because of the sampling of each area at a time, and the areas is the same height. It is possible that the large volume of water entering the orphanages relative to the amount of farmed fish, the chemical interactions did not have a potential effect on the temperature and the inlet and outlet temperatures of the farms were close to each other. (Figure 1) The temperature in autumn was significantly lower than in summer, which is scientifically correct. The results of statistical studies for temperature showed no difference between upstream and downstream areas of the study area. These results are consistent with the results of previous records (Bergheim et al., 1978). Study on a river in southwestern Norway) (Bergheim, A., \& Selmer-Olsen, A. R., 1978)

\section{$3.2 \mathrm{PH}$}

The results of $\mathrm{pH}$ measurement in the study area showed that, in summer, the $\mathrm{pH}$ level at the inlet water area is higher than 7, which means that the water is Alkaline and has become more acidic at the outlet side. In this season, the situation is similar in Gaznak area and the amount of acidity has increased from the entrance to the exit, which can be considered due to the flow of water on the sediments and also the combination with field water, which shows that water in the field is more acidic than river water. In autumn, in both Gaznak and Ab-e-Ask fields, the incoming water had lower acidity than the outgoing water and had a higher pH (Figure 2). But the autumn chart shows there is one exception, and it is that in the fall at the farm outlet. 
But the autumn chart shows an exception, and it is that in the fall at the outlet of the farm in the water area of Ask facing an increase in $\mathrm{pH}$ and a decrease in acidity, which can give the possibility at the beginning of the growing season, ponds (ponds Cement) will be sprayed lime for disinfection, And control $\mathrm{pH}$ fluctuations by spraying lime, which causes to increase the $\mathrm{pH}$ and alkalinity of the water. In this study, the $\mathrm{pH}$ varies between 6.6 and 8.1 (Figure 2). The pH should be between 6.5 and 8.5, which is consistent with the results obtained. (Iran Institute of Standards and Industrial Research) The results of statistical studies in summer do not show a significant difference between upstream and downstream, but in autumn there is a significant difference between the two regions (Table 3).

These results are in line with previous records (Mir Rasouli et al., 2012), the effect of effluent from salmon farms on the water quality of Zarrin Gol creek in Golestan, (Faghani Langroudi and Golijani Moghadam, 2008), oxygen changes due to pollution of fish farms in the river two thousand Tonekabon) (Faghani Langroudi. H. and Golijani Moghaddam), Sobhan Ardakani et al. (2011), Evaluation of the effect of fish breeding effluents on physical and chemical water quality of Kabkian river (Sobhan Ardakani, Mehrabi, S. Z., \& Ehteshami, M., 2011) (Naderi Jelodar et al. (2006), Investigation of pollution caused by rainbow trout farms on quality parameters The water of the Haraz River (Naderi Jelodar, M., \& Abdoli, A., 2011), (Fossil Degfo et al. (2010), entitled "Effects of fish farming on farms on water quality in Ethiopia", was consistent.

\subsection{Electrical Conductivity}

The results of EC measurement in the study area showed that the amount of electrical conductivity in summer in both areas showed a good amount. The amount of Gholamreza Bangar, (2009) and is also in the standard range for wastewater discharge to surface water, which should not be more than $1800 \mu \mathrm{mhos} / \mathrm{cm}$. In autumn, the amount of electrical conductivity in the stations of the two areas has increased (from input to output). In the upstream area (water area) at the inlet, the EC rate was $520 \mu \mathrm{mhos} / \mathrm{cm}$.

And at the output with a slight decrease reached $480 \mu \mathrm{mhos} / \mathrm{cm}$. At the confluence of the river water with the outflow water, the EC reached $460 \mu \mathrm{mhos} / \mathrm{cm}$. in the downstream area (Goznak region) the amount of electrical conductivity for the farm input was $620 \mu \mathrm{mhos} / \mathrm{cm}$ and at the output of the first and second workshops it was slightly reduced to 580 and $585 \mu \mathrm{mhos} / \mathrm{cm}$, respectively, and also at the confluence of the river with water. The output increased slightly to $600 \mu \mathrm{mhos} / \mathrm{cm}$ (Figure 3 ).

The reason for the increase in EC in autumn compared to summer can be attributed to the possibility of seasonal rainfall. The rains wash away the salts from different levels and transfer them into the river. The reason for the increase in the amount inside the farm compared to the summer season can be attributed to the peak of fish production and breed in this season, which increases waste and food waste.

Results in the fall ranged from 460 to $620 \mu \mathrm{mhos} / \mathrm{cm}$, allowing the US National Standard (EPA) (1996) range between 150 and 500 for natural surface waters. Therefore, in relation to this parameter in autumn, water pollution can be claimed and the reason is the mentioned probabilities.

However, according to the standards of Iranian wastewater output, this amount for this factor is $1800 \mu \mathrm{mhos} / \mathrm{cm}$, according to this standard; the permissible limit has been observed (Iran Institute of Standards and Industrial Research). The results of statistical studies showed that there is a significant difference in both areas in both seasons between upstream and downstream (Table 3).

These results are similar to the results of previous records (Naderi Jolodar et al., 2006), Investigation of pollution caused by rainbow trout farms on water quality parameters of Haraz (Naderi Jelodar, M., \& Abdoli, A., 2011) (Degfo et al., 2010), on the effect of fish farms on Water quality in Ethiopia. But these results are in line with the results of Sobhan Ardakani et al. (2011), evaluation of the effect of fish breeding effluents on the physical and chemical quality of Kabkian River water (Sobhan Ardakani, Mehrabi, S. Z., \& Ehteshami, M., 2011), which increased EC, which could increase the probability of sampling in January Rainfall and river water turbulence and soil washing and increase in solutes and thus increase EC in the region.

\section{Biological Oxygen Requirements}

The results of BOD measurement in the study area showed that in autumn and in the upstream area (Ab-e-Ask) the amount of BOD water input is $3 \mathrm{mg} / \mathrm{lit}$ and this parameter is associated with a decrease in farm water output and is reduced to $1 \mathrm{mg} / \mathrm{lit}$. At the confluence of the outlet water with the river water, it has reached $5 \mathrm{mg} / \mathrm{lit}$ with a slight increase. This trend is repeated in the summer. The BOD level in the water entering the field was $4 \mathrm{mg} / \mathrm{lit}$ and in the output was close to $0 \mathrm{mg} / \mathrm{lit}$. (Figure 4) The reason for changing this parameter at the entrance and exit of the farm can be the possibility of low feeding or evacuation of pools. Downstream of the river (Goznak area) in autumn the amount of BOD in the water inlet is $4 \mathrm{mg} / \mathrm{lit}$ and in the output of the first workshop (station 5) this amount reached 
$6 \mathrm{mg} /$ lit and in the outlet of the second farm (station 6) to $\mathrm{mg} / \mathrm{lit} 9$ increased. The effluent from the second farm intersected with the river water and reached $7 \mathrm{mg} / \mathrm{lit}$. An increase of $2 \mathrm{mg} / \mathrm{lit}$ and $3 \mathrm{mg} / \mathrm{lit}$ in the first and second farms, respectively, could possibly indicate water contamination by food and excreted fish. This contaminant enters the river water without filtering and then is used in agricultural fields, which causes contamination of crops. It also contaminates soil and groundwater along the river and eventually dumps into the sea, causing pollution. In summer, the analysis showed that the amount of BOD at the inlet of $5 \mathrm{mg} / \mathrm{lit}$, the amount of BOD at the outlet of the first farm was $5 \mathrm{mg} / \mathrm{lit}$ and at the outlet of the second farm was $6 \mathrm{mg} / \mathrm{lit}$ and at the station where the river water intersects with the outlet with Slight decrease to $5 \mathrm{mg} /$ lit (Figure 4). A slight increase in BOD because of a decrease in farm activity in the summer, as the best time to raise fish is in the second half of the year. According to the standards of wastewater discharge for discharge to surface waters, the permissible amount of BOD is $30 \mathrm{mg} / \mathrm{lit}$, which means that in this study, river water is in a clean range. In summer, farms usually start preparing ponds, such as disinfecting and spraying lime, and so on. The spawning and arrival stages of juveniles also take place in the summer, when they use more drugs and disinfectants than food to prevent disease and death. The peak activity of the fields is also in autumn and with the growth of fish, which increases BOD. According to the results of statistical studies, no significant difference was observed between the upstream and downstream regions in both seasons (Table 3). These results with the results of previous similar records (Amirkolaei, 2009), factors affecting the environmental conditions of Haraz River (Naderi Jelodar et al., 2006). Investigation of pollution caused by rainbow trout farms on water quality parameters of Haraz River (Naderi Jelodar, M., \& Abdoli, A., 2011), Bergheim and Salmer (1978), on farms located on a river in Norway. (Bergheim, A., \& Selmer-Olsen, A. R., 1978)

\section{Soluble Solids (TDS)}

Referring to Figures 5 and 3, it can be seen that whenever the TDS increased, the EC also increased, and wherever the TDS decreased, the EC also decreased. The results of TDS in the study area showed that the amount of TDS in the upper reaches of the river (Ab-e-Ask) in summer varied from $186 \mathrm{mg} / \mathrm{lit}$ to $188.7 \mathrm{mg} / \mathrm{lit}$. In the downstream area (Gaznak), this parameter also changed and increased from $204 \mathrm{mg} /$ lit to $210.2 \mathrm{mg} /$ lit (Figure 5). In autumn, however, the amount of TDS in the incoming water was higher than in summer and in the upstream area, it showed $356 \mathrm{mg} / \mathrm{lit}$. At the outlet this value reached $326 \mathrm{mg} / \mathrm{lit}$ and at the confluence of the river water with the outlet water decreased to $314 \mathrm{mg} / \mathrm{lit}$. Also downstream, this level increased from $422 \mathrm{mg} / \mathrm{lit}$ to $408 \mathrm{mg} / \mathrm{lit}$ at the confluence of river water with outflow water (Figure 5). The allowable TDS is $1500 \mathrm{mg} / \mathrm{lit}$, which shows that the results obtained in both seasons are less than this amount (Iran Institute of Standards and Industrial Research). From the perspective of this factor, there is no water pollution. The general increase in TDS in autumn compared to summer. It can be an increase of rainfall and leaching of solutes in the soil, and also in autumn the activity of farms has increased, which has increased fish and more water pollution. These results are similar to the results of previous records (Naderi Jelodar et al., 2006), investigation of pollution caused by rainbow trout farms on water quality parameters of Haraz (Naderi Jelodar, M., \& Abdoli, A., 2011), (Ardakani et al., 2011), evaluation of the effect of reproduction effluents and Fish farming corresponded to the physical and chemical quality of the water of the Kabkian River (Sobhan Ardakani, Mehrabi, S. Z., \& Ehteshami, M., 2011), The results of statistical studies also show that in autumn it was not no significant difference between upstream and downstream, but in summer this difference is significant (Table 3).

\section{Nitrite}

The results of nitrite measurement in the study area showed that in the water input station of the upstream farm in the fall was less than $0.003 \mathrm{mg} / \mathrm{lit}$. This amount is less than the accuracy of the measuring device and the value of 0 is specified in the results. At the outlet station of the mentioned farm, the amount of nitrite to $0.005 \mathrm{mg} / \mathrm{lit}$. Increased and also reached $0.008 \mathrm{mg} / \mathrm{lit}$ at the confluence of the outlet water with the river water. In the downstream area, this rate reached $0.06 \mathrm{mg} /$ lit at the inlet and 0.067 and $0.069 \mathrm{mg} / \mathrm{lit}$ at the first and second outlets, respectively. (Figure 6) Increased nitrite in the downstream area may be due to the presence of restaurants and recreation centers along the river, and the increase in nitrite at the confluence of the downstream area is due to the concentration of two fish farms in one area, which increases the density and concentration of nitrite. Also, upstream of the river, the flow rate has been higher and in this area facing less polluting sources than downstream. On the other hand, it is possible that in this season, due to precipitation and the existence of Nitrogen cycle and conversion of Nitrogen to Nitrite by nitrosamines bacteria in the soil and washing it by rain, nitrite will increase compared to summer (Nafri Yazdi, 2011). In summer, as in autumn, in the upstream area (Ab-e-Ask), the amount of Nitrite in the water inlet was $0.004 \mathrm{mg} / \mathrm{lit}$ and the outlet was slightly reduced to $0.003 \mathrm{mg} / \mathrm{lit}$. Then at the confluence of the outlet water with the river water, this amount increased to $0.004 \mathrm{mg} / \mathrm{lit}$. In the downstream area (Gaznak) at the input station such as autumn, the researchers encountered a significant increase in Nitrite and at the input, the first and second outputs $0.021,0.021$ and $0.024 \mathrm{mg} / \mathrm{lit}$, respectively, and also at the intersection of 
the outlet water with water The river reached $0.022 \mathrm{mg} /$ lit. (Figure 6) The reason for the increase in nitrite in the output, in addition to the possible cases in the fall, could be most likely due to ammonia (urine) excreted by fish and reduced ammonia absorption by plankton due to reduced plankton in the summer, which is the result of fluctuations. It is followed by an increase in nitrification bacteria and nitrite concentration in the water. According to the standards of wastewater discharge for discharge to surface waters, the amount of nitrite is $10 \mathrm{mg} / \mathrm{lit}$, therefore, the amount of nitrite obtained at the stations does not indicate water pollution and from the point of view of this factor, there is no water pollution. Statistical studies also show a significant difference in the two chapters between upstream and downstream. (Table 3) These results are similar to the previous records (Naderi Jolodar et al., 2006). Investigation of pollution caused by rainbow trout farms on the water quality parameters of Haraz River (Naderi Jelodar, M., \& Abdoli, A., 2011), Nafri Yazdi et al. (2011), on the study of effluent quality of rainbow trout farms in Haraz River was consistent.

\section{Nitrate}

The results of nitrate measurement in the study area showed that the amount of nitrate in autumn at the inlet station of Ab-e-Ask area, which is upstream of the river, is $3.17 \mathrm{mg} / \mathrm{lit}$ which is $48 \mathrm{mg} / \mathrm{lit}$ at the outlet. 3 must increase. This amount reaches $3.59 \mathrm{mg} / \mathrm{lit}$ at the confluence of river water with the outlet of the farm with a slight increase, which can be attributed to the activity of fish in the farm. In the Gaznak area, which is downstream of the river, the amount of nitrate at the inlet station is $3.65 \mathrm{mg} /$ lit, which is slightly higher than the water area of Ask, which seems reasonable considering the downstream of the river in this area. At the exit station of Gaznak area, at the exit of the first workshop, the amount of nitrate with a slight increase was 4.32 $\mathrm{mg} / \mathrm{lit}$. The reason for this increase can be attributed to the increase in fish activity and feeding rate. But in the output of the second workshop, we are faced with a slight decrease compared to the output of the first workshop by $4.05 \mathrm{mg} / \mathrm{lit}$. In the confluence of river water with farm output, we have an increase of nitrate by $4.85 \mathrm{mg} / \mathrm{lit}$, which seems reasonable considering the concentration of the output of two farms in that area (Figure 8). In summer, the researchers faced a significant decrease in Ab-e-Ask area compared to autumn, which can be attributed to the possibility of rain in autumn and soil washing by rain and increased field activity in this season. In summer, the amount of nitrate is $0.5 \mathrm{mg} / \mathrm{lit}$ at the water intake station and at the outlet station and the intersection of the outlet water with the river water with a slight increase of $0.8 \mathrm{mg} / \mathrm{lit}$, which is due to increased fish activity. In the Gaznak area at the inlet station, the nitrate content was $0.9 \mathrm{mg} / \mathrm{lit}$, which did not change much compared to the water area of Ask at the same point, which indicates that the river water did not change much along the route from upstream to downstream in terms of Nitrate content. In the outputs of the first and second workshops, the amount of nitrate for both decreased to $0.8 \mathrm{mg} /$ lit and in the confluence of the river water with the outlet of the workshop with a slight increase in nitrate to $0.9 \mathrm{mg} / \mathrm{lit}$. According to the standards of wastewater discharge for discharge to surface waters, the permissible level for nitrate is $50 \mathrm{mg} /$ lit. According to statistical studies, nitrate shows a significant difference in autumn but no significant difference in upstream and downstream in summer (Table 3). Output of salmon farms on water quality of Zarrin Gol creek in Golestan province, Mehdi Naderi Jelodar et al. (2006), the effect of fish farm effluent on water quality of Haraz River (Naderi Jelodar, M., \& Abdoli, A., 2011), Nafri Yazdi et al. (2011), on the study of effluent quality of rainbow trout farms in Haraz Bergheim and Salmer (1978) corresponded to a fish farm in Norway. (Bergheim, A., \& Selmer-Olsen, A. R., 1978)

\section{Phosphate}

The results of phosphate measurement in the study area in this study showed that the concentration of phosphate in autumn in the area of Ab-e-Ask, which is upstream of the river at the inlet station was less than $0.01 \mathrm{mg} /$ lit, which is less than The accuracy limit of the device was considered to be zero, this rate reached $0.01 \mathrm{mg} /$ lit at the outlet station and the confluence of river water with outlet water, which was due to the increase in field activity. In Goznak area, which is downstream of the river, in the same autumn season, the amount of phosphate was 0.02 $\mathrm{mg} / \mathrm{lit}$ at the inlet station, and $0.03 \mathrm{mg} / \mathrm{lit}$ at the outlet of the first and second workshops, and also at the confluence of river water with farm outlet Slight reduction to $0.02 \mathrm{mg} / \mathrm{lit}$. The numbers obtained indicate that for both areas in the fall there is not much change in the fall and only in the outputs the amount of phosphate increased slightly (Figure 9). The amount of phosphate in summer in the water Ask area at the input station is $0.1 \mathrm{mg} / \mathrm{lit}$ and at the output station with a relative increases to $0.4 \mathrm{mg} / \mathrm{lit}$ and then has a sudden decrease to $0.1 \mathrm{mg} / \mathrm{lit}$ at the local station. The confluence of the river water with the outflow water. The amount of phosphate in Gaznak area at the inlet station was $0.2 \mathrm{mg} / \mathrm{lit}$ which reached $0.6 \mathrm{mg} / \mathrm{lit}$ with a sudden increase in the outlet station of the first workshop and then with a decrease in the outlet of the second workshop and the confluence of the river and Field effluent reaches $0.2 \mathrm{mg} /$ lit (Figure 9). As it turned out, the amount of phosphate in summer is much higher than in autumn. It can be attributed to the decrease in river discharge and increase in temperature and consequently the decrease in 
oxygen to decompose phosphate, and also because we are facing the preparation of farms for breeding in the summer and therefore drugs, antibiotics and disinfectants are used. Another is the increase in phosphate in the summer. The permissible level for phosphate is $6 \mathrm{mg} /$ lit, therefore, according to the experiments performed and according to Figure 9, phosphate from fish farms has no effect on river pollution in terms of this factor. (Iran Institute of Standards and Industrial Research) Based on the results of statistical studies, the amount of phosphate in autumn and summer showed a significant difference between upstream and downstream. (Table 3 ) These results with the results of similar previous records (Mir rasoli et al., 2012) on the effect of effluent on trout farms Zarrin Gol, Golestan Province, Naderi Jelodar et al. (2006), The effect of fish farm effluent on water quality of Haraz River (Naderi Jelodar, M., \& Abdoli, A., 2011), Nafri Yazdi et al. (2011), on the study of effluent quality of rainbow trout farms in Haraz, Bergheim and Salmar (1978) rivers, on the river Norway (Bergheim, A., \& Selmer-Olsen, A. R., 1978), Gilpart et al. (2012) corresponded to the effect of farm effluents on rivers in France. (Guilpart, A., Roussel, J. M., Aubin, J., Caquet, T., Marle, M., \& Le Bris, H., 2012)

\section{Ammonia}

The results of Ammonia assay in the study area showed that in autumn the amount of this factor at the inlet of the upstream area was less than $0.01 \mathrm{mg} /$ lit, which was beyond the accuracy of the device. In the field output, however, an increase in Ammonia was observed and reached $0.11 \mathrm{mg} / \mathrm{lit}$. Also, at the confluence of the outlet water with the river water, this amount decreased to $0.04 \mathrm{mg} / \mathrm{lit}$. In the downstream area, the amount of Ammonia in the inlet water was $0.1 \mathrm{mg} /$ lit and increased to $0.21 \mathrm{mg} /$ lit in both outlets. Also, at the confluence of the outlet water with the river water, this amount reached $0.19 \mathrm{mg} /$ lit. (Figure 7) The results obtained in this chapter show an increase in water pollution at farm output, which of course was also predictable. In summer, in the upstream area, the inflow rate was $0.14 \mathrm{mg} /$ lit and the output was $0.27 \mathrm{mg} / \mathrm{lit}$, and at the confluence of the outflow water with the river water, this rate reached $0.25 \mathrm{mg} / \mathrm{lit}$. Downstream, 0.30 .51 and $0.69 \mathrm{mg} / \mathrm{lit}$ were observed for the second inlet, outlet and second outlet, respectively, and also reached $0.68 \mathrm{mg} / \mathrm{lit}$ at the confluence of the outlet water with the river water (Figure 7). Possible factors that can increase Ammonia in the outlets, including, in summer due to increased migration to these cold regions, along the Haraz River, the amount of ammonia entering the water due to human biological activities along the way from upstream to downstream increases. Also, decrease in flow and increase in temperature are other factors that increase Ammonia in this season. The permissible level for ammonia is $2.5 \mathrm{mg} / \mathrm{lit}$, as a result of which the level in the water of the studied river has not exceeded the permissible limit and the river water is clean from the point of view of this factor. In both seasons and in both areas, the amount of Ammonia at the entrance is lower than the output of the field; this result is quite predictable and logical because the amount of ammonia is directly related to the excretion of fish and fish activity. The results of statistical studies showed a significant difference in both seasons upstream and downstream of the river. (Table 3) These results with the results of similar previous records (Naderi Jolodar et al., 2006), the effect of fish farm effluent on water quality of Haraz River (Naderi Jelodar, M., and Abdoli, A., 2011), Ardakani et al. (2011), Evaluation of the effect of effluent from fish breeding and breeding workshops on the physical and chemical quality of water in Kabkian River (Sobhan Ardakani, Mehrabi, S. Z., and Ehteshami. M., 2011), Nafri Yazdi et al. (2011) on the study of effluent quality of rainbow trout farms in Haraz, Gilpart et al. (2012) corresponded to the effect of farm effluents on rivers in France. (Guilpart, A., Roussel, J. M., Aubin, J., Caquet, T., Marle, M., \& Le Bris, H., 2012)

\section{Total Organic Carbon}

The results of TOC measurement in the study area showed that the amount of organic carbon in autumn in the area of Ab-e-Ask (upstream) at the inlet station is $4 \mathrm{mg} /$ lit and at the outlet station suddenly reaches $1 \mathrm{mg} /$ lit and then at the site. At the confluence of the workshop with the effluent, the amount of organic carbon reaches $6 \mathrm{mg} / \mathrm{lit}$ with a significant increase. In the same season, in the Gaznak area, which is downstream of the river, the amount of organic carbon in the incoming water was $4 \mathrm{mg} / \mathrm{lit}$, which corresponds to the incoming water of the upstream area, and this indicates the absence of a source of pollution along the way from the upstream to Downstream. In the output stations of the first and second workshops, the amount of organic carbon reaches 8 and $10 \mathrm{mg} / \mathrm{lit}$, respectively, with a significant increase, which is reasonable considering the activity of the workshops, increasing the organic carbon in the outputs (Figure 10). In summer, the amount of organic carbon is $0.811 \mathrm{mg} / \mathrm{lit}$ in the water station area at the inlet station and 0.901 and $1.165 \mathrm{mg} /$ lit at the outlet station and the intersection station of the river water with a slight increase, respectively. It turns out that it makes sense given the activity of the farms. In Gaznak area, organic carbon at the input station reaches $0.989 \mathrm{mg} / \mathrm{lit}$, which has slightly increased compared to the input station in Ab-e-Ask area, and at the output stations of the first and second workshops, organic carbon is 1.189 and $1.4646 \mathrm{mg} / \mathrm{lit}$. This increase is reasonable considering the activity of the farms. At the intersection station with the water of the river, the amount of organic carbon with a slight decrease of $1.370 \mathrm{mg} /$ lit shows (Figure 10). Also, 
statistical studies do not show a significant difference between the upstream and downstream regions in autumn, but there is a significant difference between the two regions in summer (Table 3).

\section{Chemical Required Oxygen}

The results of COD measurement in the study area showed that the level of COD in autumn in the area of $\mathrm{Ab}$-e-Ask, which is upstream of the river, was $6 \mathrm{mg} / \mathrm{lit}$, which means that the river itself is somewhat chemically polluted, which can be the cause. Considered the possibility of contaminant sources such as restaurants, at the outlet station with a slight decrease in COD reaches $2 \mathrm{mg} / \mathrm{lit}$ and at the station where the river intersects with the outlet water increases to $9 \mathrm{mg} /$ lit (Figure 11). In the Gaznak area, which is downstream of the river, at the COD inlet station shows a value of $7 \mathrm{mg} /$ lit, which has increased slightly compared to the inlet area upstream, this increase may be due to other pollutants such as restaurants or workshops that they are located downstream along the river. The COD at the output station of the first workshop shows $12 \mathrm{mg} / \mathrm{lit}$, which has increased, and at the exit station of the second workshop, the rate of $17 \mathrm{mg} / \mathrm{lit}$, which may be due to activities such as dumping drugs and fungicides in Inside fish ponds. At the station at the confluence of the effluent with the river water, the COD level decreased slightly to $13 \mathrm{mg} / \mathrm{lit}$. In summer, the COD level in the water Ask area was $0.2 \mathrm{mg} / \mathrm{lit}$ at the input station, which was considered zero in the diagram because it was less than the accuracy of the measuring device, and was also zero at the COD output station, but at the intersection. The river water with the water leaving the workshop reached $43 \mathrm{mg} / \mathrm{lit}$ with a significant increase. In Gaznak area in the same season at the inlet station the COD rate was $0.8 \mathrm{mg} /$ lit, which is slightly higher than the inlet water area, and this increase, like in autumn, may be due to sources of pollutants along the river from upstream to be downstream. At the output station of the first workshop, the COD test showed a value of $1.2 \mathrm{mg} /$ lit, which increased in proportion to the incoming water, which is due to the activities inside the workshop. At the output station of the second workshop, there was a sudden increase in COD, and reached $41.3 \mathrm{mg} / \mathrm{lit}$ and at the station where the river water intersects with the outflow water, the COD level decreased slightly to $41 \mathrm{mg} /$ lit (Figure 11). The value obtained from the tests for this factor is also within the permissible limits of wastewater output standards, ie less than $60 \mathrm{mg} / \mathrm{lit}$ (Iran Institute of Standards and Industrial Research). According to the results of statistical studies, there was no significant difference between the upstream and downstream regions in both seasons (Table 3).

These results were consistent with the results of previous records (Ardakani et al., 2011), on the effect of fish farms effluent on the water quality of the Kabkian River. (Sobhan Ardakani, Mehrabi, S. Z., \& Ehteshami, M., 2011) However, the amount of COD in this study, which was conducted on the water of Haraz River, is higher than the amount of COD in the Kabkian River, which indicates that there are more activities done around the river, such as aquaculture, restaurants and settlements.

\section{Conclusion}

The results showed that for the factors of temperature, nitrite, nitrate, amount of soluble solids, total organic carbon, $\mathrm{pH} \mathrm{BOD}$, according to the tests performed and the results obtained, all these factors were within the allowable level of wastewater discharge standards. The numbers were higher in the fall than in the summer, which can be attributed to the increase in farm activity in this season. Also, the results of these factors were consistent with previous articles and research. In summer it was more than autumn because of the decrease in water flow, increase in temperature and increase in human activities in this season about ammonia factor. According to articles and researches inside and outside of the country, the increase of these three factors in summer compared to autumn corresponded to them.

In general, the results of this study indicate the appropriate quality of river water.

\section{References}

Arjmandi, R., Karbasi, A., \& Mogoei, R. (2007). Study of the environmental effects of aquaculture in Iran. Environmental Science and Technology, 9(2).

Bergheim, A., \& Selmer-Olsen, A. R. (1978). River pollution from a large trout farm in Norway. Aquaculture, 14(3), 267-270. https://doi.org/10.1016/0044-8486(78)90100-X

EPA. (1996). Quality criteria for waters. Washington D.C.

Faghani Langroudi, H., \& Golijani Moghaddam. (2008). Comparison of final fish production in consecutive ponds of rainbow trout farming workshop.

General Department of Fisheries of Mazandaran Province. (2005). Final report on salmon production potential in Haraz River. Sari: General Department of Fisheries of Mazandaran Province. 
Guilpart, A., Roussel, J. M., Aubin, J., Caquet, T., Marle, M., \& Le Bris, H. (2012). The use of benthic invertebrate community and water quality analyses to assess ecological consequences of fish farm effluents in rivers. Ecological Indicators, 23, 356-365. https://doi.org/10.1016/j.ecolind.2012.04.019

Iran Institute of Standards and Industrial Research. No. 1053; First Edition; Drinking water - physical and chemical properties.

Iran Institute of Standards and Industrial Research. No. 2347; First Edition; Water sampling method.

Ismail Sari. (2004). Hydrochemistry: Aquaculture Foundation. Tehran: Aslani Publications.

Kazemzadeh Khajoui, A., Ismaili Sari, A., \& Qasem Poori, S. (2002). Investigation of pollution caused by salmon farms in Haraz River.

Naderi Jelodar, M., \& Abdoli, A. (2011). Large response of benthic invertebrates of Haraz river to the effluent of our colorful trout farms. Fisheries, 64(2), 163-175.

Naderi Jelodar, M., \& Abdoli, A. (2011). Large response of benthic invertebrates of Haraz River to the effluent of our colorful trout farms. Fisheries, 64(2), 175.

Sepahdari, Saeedi, Kakolki, Shapoor, Habibi Kotnaei, Farshideh, \& Babaalian. (2013). The effect of environmental risk factors on the incidence of streptococcus in rainbow trout farms (Onchorhynchus mykiss) Haraz River by Logistic Regression. Iranian Journal of Fisheries, 22(3), 60-73.

Sobhan Ardakani, Mehrabi, S. Z., \& Ehteshami, M. (2011). Evaluation of the effect of effluent from fish breeding workshops on the physicochemical quality of water in the Kabkian River.

Statistical Yearbook of Iran Fisheries Organization. (2009). Program and Budget Office, Department of Statistics and Fisheries Development Studies.

Zamanpour, M. (2008). Final report of the research project to study the effluent changes of salmon farms in the catchment area of Dorodzan dam. Agricultural and Natural Resources Research Center of Fars Province.

\section{Copyrights}

Copyright for this article is retained by the author(s), with first publication rights granted to the journal.

This is an open-access article distributed under the terms and conditions of the Creative Commons Attribution license (http://creativecommons.org/licenses/by/4.0/). 